\title{
Infection and Chemotherapy, 대한감염학회와 대한화학요법학회의 공동발행 학술지
}

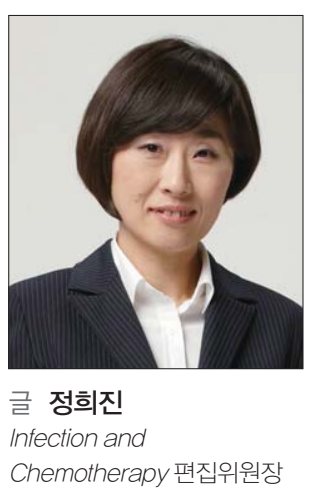

\section{『감염과 화학요법』에서 Infection and Chemotherapy까지}

Infection and Chemotherapy는 2003년, 대한감 염학회에서 발행하던 『감염』지와 대한화학요법학회에 서 발행하던 『대한화학요법학회지』가 발전적으로 통합 하여 새로이 탄생한 양 학회 공동학술지입니다. 『감염』 지는 1969년 창간호가 만들어진 이후 14 년이 지난 1982년 제16권부터 연간 2회로 발간 횟수가 증가되었 고, 1987 년 제 19 권부터는 연간 4 회로 늘었습니다. 1994년 편집체계가 본격적으로 정비되기 시작하면서 창간호부터 사용했던 투고규정을 개정하고, ISSN에 등록함으로써 여러 문헌 검색책자에서의 검색이 가능 하게 되었으며, 1997 년 제 29 권부터는 발행주기를 연간
6 회로 증가시켜 학회지 평가에서도 우수하다는 평가를 받게 되었습니다. 1998 년부터는 '편집인에게로의 편 지'가 처음 신설되었고, 투고규정을 '논문제출 및 작성 에 관한 지시사항 으로 변경하였으며 저자 확인사항 기 록양식을 만들었습니다. 1999년부터는 저자와 색인단 어 및 총목차를 게재하여 알아보기 쉽게 함으로써 명실 상부한 학회지의 모습을 갖추게 되었습니다. 학회지 표 지는 창간되던 1969년부터 1997년까지 큰 변화를 보이 지 않다가(1971년 영문표기만 'Journal of Korean Infectious Diseases' 에서 'Korean Journal of Infectious Diseases'로 바뀜) 1998년 개정되었습니 다. 대한화학요법학회가 학회 창립 25주년이던 1983년 5월 창간한 『대한화학요법학회지』를 1996년까지 연 2 회 발행하다가 1997년부터는 연 4회 발행하던 『감염』 
지와 통합했던 것입니다. 이렇게 7년간 『감염과 화학요 법(Infection and Chemotherapy)』으로 발행되던 학 술지는 2010년 과학기술논문 인용색인(SCI, Science Citation Index), 스코퍼스(Scopus) 등재 등 세계적 학술지로 도약하기 위한 준비의 일환으로 제목에서 국 문명『감염과 화학요법』을 삭제하고 영문명 Infection and Chemotherapy로 거듭나게 되었습니다. 뿐만 아 니라 학회지 디자인 및 내용도 심혈을 기울여 대대적으 로 개편하여 지금까지 그 모습을 유지하고 있습니다.

2008년부터는 온라인투고시스템 (http://submit. icjournal.org)을 개설하면서 투고자뿐 아니라 심사위 원들도 편리하게 심사할 수 있게 되었으며 이로 인해 우편으로 주고받던 심사의 번거로움과 시간이 단축되 었으며, 투고된 논문들을 좀 더 체계적으로 관리할 수 있게 되었습니다. 온라인 투고시스템이 개설될 때 학회 지 논문들을 책자를 통해서만 보는 것이 아니라 웹에서 원문으로 확인 할 수 있는 학회지 홈페이지(http://www. icjournal.org)도 함께 개설되었고, 모든 논문의 원문 을 이용하는 데에 기여하게 되었습니다. 뿐만 아니라 학회지 홈페이지를 개설함과 동시에 eISSN을 부여받 아 온라인 출판물로서도 인정받게 되었습니다. 그뿐만 아니라 2008년 이후로는 한국의학학술지편집인협회의 KoreaMed Synapse를 통하여 각 논문마다 DOI(Digital Object Identifier)를 부여받아 세계 어디서나 쉽게 논 문을 검색하여 이용할 수 있게 되었고, 더 많은 독자들 이 논문을 자유롭게 읽고 인용할 수 있도록 오픈 액세 스(open access) 저널로 운영하고 있습니다.

그러나, 우리 학회지에도 우여곡절이 있었습니다. 한 국연구재단의 등재후보지였던 우리 학술지는 아주 사 소한 실수들을 해서 2007년도 등재후보지에서 탈락되 는 수모를 겪기도 했습니다. 그러나 2008년 새롭게 평 가를 신청하여 등재후보지에 재등록되었고, 2010년 등
재후보지 1차 평가를 통과한 데 이어 2011년 2차 평가 를 통과하여 한국연구재단의 등재지로 등록되었습니 다. 그뿐만 아니라 2011년도에는 Scopus에도 등재되 면서 더 많은 선생님들이 Infection and Chemotherapy 를 접할 수 있게 되었습니다. 또한 2012년도에는 영광스 럽게도 한국과학기술단체총연합회의 학회지 평가에서 의학계열 학술지 중 최고점수를 획득하게 되었습니다.

\section{새로운 변화가 시작되는 2013년}

Infection and Chemotherapy는 매년 6회 발행되 던 국문 · 영문 혼용 학회지에서 2013년도부터는 발행 횟수를 연 4회로 변경하고 모든 논문을 영문으로만 발 행하는 영문지로 전환할 계획입니다. 영문지로의 전환 을 위하여 영문편집위원회(editorial board), 투고규 정, 학회지 홈페이지, 온라인 투고 시스템을 모두 재 정비하는 작업을 진행 중에 있으며 더 좋은 논문이 많 이 투고될 수 있도록 대대적인 홍보를 위해 힘쓰고 있 습니다.

이러한 영문지로의 전환이 Infection and Chemo therapy가 세계적인 학회지로 거듭나는 데에 큰 역할 을 할 것이라고 생각합니다. 또한 SCI, PubMed 등재 까지 힘든 과정들이 있겠지만 이전과 마찬가지로 꾸준 히 노력할 예정입니다.

아직 많이 부족하고 더 좋은 학회지가 되기 위해 할 일이 많이 남아 있지만, 양 학회의 간행위원, 임원, 심사 위원들의 많은 참여와 관심, 그리고 무엇보다 우리 학회 지에 좋은 논문을 투고해주신 많은 선생님이 계셨기에 지금의 모습으로 성장 가능하였다고 생각됩니다. 0 